\title{
ANALISIS KEBUTUHAN AIR IRIGASI UNTUK LAHAN PERSAWAHAN DUSUN TO'PONGO DESA AWO GADING KECAMATAN LAMASI
}

\author{
Andi Kartini Sari ${ }^{1)}$ \\ 1) Dosen Program Studi Teknik Sipil, Universitas Andi Djemma, Palopo \\ 1)
}

\begin{abstract}
Abstrak
Irigasi merupakan bangunan air yang berupa saluran dan berfungsi menyalurkan air dari bendung ke petak secara periodik, guna mencukupi kebutuhan air bagi tanaman di petak sawah oleh karena itu investasi irigasi menjadi sangat penting dan strategis dalam rangka penyediaan air untuk pertanian. Dalam memenuhi kebutuhan air untuk berbagai keperluan usaha tani, maka air (irigasi) harus diberikan dalam jumlah, waktu, dan mutu yang tepat, jika tidak maka tanaman akan terganggu pertumbuhannya yang pada gilirannya akan mempengaruhi produksi pertanian. Berdasarkan hal tersebut, maksud penelitian ini adalah untuk mengetahui pengaruh kebutuhan air terhadap hasil produksi pertanian pada daerah irigasi Lamasi Kiri dusun To'Pongo Desa Awo Gading Kecamatan Lamasi. Dengan luas areal sebesar 92 ha, lahan persawahan dusun To’Pongo di Desa Awo Gading, Kecamatan Lamasi, areal persawahannya memanfaatkan air irigasi bersumber dari saluran induk Bendung Lamasi dan air hujan sehingga air dapat sampai ke areal persawahan. Dari hasil analisis pengaruh kebutuhan air terhadap hasil produksi pertanian khususnya padi berdasarkan perhitungan didapatkan bahwa produktivitas padi musim rendeng (padi musim hujan) sebesar 7,6 ton/ha menghasilkan produksi pertanian yang cukup besar yaitu sebesar 699,2 ton. Sedangkan produktivitas padi musim gadu (padi musim kemarau) sebesar 7,2 ton/ha hanya menghasilkan produksi pertanian sebesar 662,4 ton
\end{abstract}

Kata Kunci: Irigasi, kebutuhan air, produksi pertanian

\section{PENDAHULUAN}

Air adalah salah satu zat yang penting bagi semua makhluk hidup di muka bumi. Wujudnya bisa berupa cairan, es (padat) dan uap/gas. Bisa dikatakan, karena air maka Bumi menjadi satu-satunya planet dalam tata surya kita yang memiliki kehidupan (Parker 2017).

Air merupakan hal yang sangat penting bagi keberlangsungan makhluk hidup di dunia ini. Jadi dengan kata lain air merupakan suatu hal yang sangat berharga sekali. Air dapat dimanfaatkan untuk keperluan irigasi.

Irigasi bagi tanaman padi berfungsi sebagai penyedia air yang cukup dan stabil untuk menjamin produksi padi. Luas tanah atau sawah di dalam daerah pengairan di bagi - bagi sedemikian rupa sehingga memudahkan pembagian airnya. Adapun cara pembagiannya tergantung pada tujuan pengairan itu dan kebutuhan air untuk persawahan. Air yang di salurkan ke sawah melalui sistem jaringan yang terdiri atas saluran - saluran air dengan bangunan pengendali.

Kapasitas irigasi dalam kaitannya dengan ketersediaan air untuk tanaman padi dapat dikaji melalui permasalahan irigasi, dan faktor - faktor yang mempengaruhi terhadap pengelolaan air irigasi. Ketersediaan air irigasi untuk tanaman padi sawah banyak di pengaruhi oleh beberapa faktor kondisi tanah, jenis tanaman, iklim, topografi, sosial, ekonomi dan budaya masyarakat.

Tanaman padi merupakan tanaman yang banyak membutuhkan air, khususnya pada saat tumbuh mereka harus selalu tergenangi air. Agar produktivitas padi dapat efektif dalam satu satuan luas lahan, maka dibutuhkan suplay air yang cukup melalui 
irigasi. Irigasi merupakan prasarana untuk meningkatkan produktifitas lahan dan meningkatkan intensitas panen per tahun. Tersedianya air irigasi yang cukup terkontrol merupakan input untuk meningkatkan produksi padi.

Lahan persawahan dusun To'Pongo di Desa Awo Gading, Kecamatan Lamasi, areal persawahannya memanfaatkan air irigasi bersumber dari saluran induk Bendung Lamasi sehingga air dapat sampai ke areal persawahan.

Pada musim kemarau kebutuhan air persawahan Desa Awo Gading khususnya di dusun To'Pongo belum dapat terpenuhi, sehingga mempengaruhi hasil produksi petani. Hal demikian terjadi kemungkinan dikarenakan pengolahan air irigasi dan management distribusinya masih kurang merata. Pengelolaan jaringan irigasi akan mempengaruhi sistem pemberian air pada petak-petak sawah dan tingkat pelayanan irigasi yang diterima petani. Agar jaringan irigasi tersebut dapat digunakan sesuai dengan fungsinya, maka dipandang perlu untuk mengadakan analisa kebutuhan air, termasuk kebutuhan air pada daerah persawahan dimana air yang di ambil dari bendung melalui saluran irigasi haruslah seimbang dengan jumlah air yang tersedia.

Pada umumnya padi di daerah ini ditanami dua kali setahun, dengan mengandalkan air irigasi dari bendung dan air hujan. Mengingat pentingnya pengaruh kebutuhan air terhadap hasil produksi pertanian pada lahan persawahan maka dalam penelitian ini akan dikaji seberapa besar Kebutuhan Air Irigasi untuk Lahan Persawahan Dusun To'Pongo Desa Awo Gading Kecamatan Lamasi sehingga permasalahan yang ada dapat teratasi.

\section{Pengertian Irigasi}

Irigasi merupakan bangunan air yang berupa saluran dan berfungsi menyalurkan air dari bendung ke petak secara periodik, guna mencukupi kebutuhan air bagi tanaman di petak sawah. Air merupakan salah satu faktor penentu dalam proses produksi pertanian. Oleh karena itu investasi irigasi menjadi sangat penting dan strategis dalam rangka penyediaan air untuk pertanian.

Dalam memenuhi kebutuhan air untuk berbagai keperluan usaha tani, maka air (irigasi) harus diberikan dalam jumlah, waktu, dan mutu yang tepat, jika tidak maka tanaman akan terganggu pertumbuhannya yang pada gilirannya akan mempengaruhi produksi pertanian (Purwanto, Jazaul. 2014).

\section{Tahapan Pemberian Air pada Tanaman Padi}

Kebutuhan air sangat diperlukan tanaman padi sawah untuk pertumbuhan. Adapun macam - macam kebutuhan air di lahan sawah tanaman padi yaitu :

Fungsi air bagi tanaman bermacam - macam antara lain: (1)untuk proses fotosintesis tanaman membutuhkan air, udara dan sinar matahari, (2)air berfungsi membawa karbohidrat dan mineral kebagian - bagian tanaman sebagai cadangan makanan, (3)penguapan air berguna untuk kestabilan suhu di sekitar tanaman, pori - pori daun akan tertutup apabila kadar air kedalam daun terlalu kecil, dan air yang cukup diserap oleh tanaman padi sebagian besar hilang lewat penguapan.

\section{Pola Tanam}

Untuk memenuhi kebutuhan air tanaman, penentuan pola tanam merupakan hal yang perlu dipertimbangkan. Tabel di bawah ini merupakan contoh pola tanam yang di pakai. 
Tabel 1. Pola Tanam Daerah Irigasi (Sidharta, SK. 2013).

\begin{tabular}{cll}
\hline No & Ketersediaan Air untuk Jaringan Irigasi & \multicolumn{1}{c}{ Pola Tanam dalam Satu Tahun } \\
\hline \multirow{2}{*}{1} & Tersedia air cukup banyak & Padi - Padi - Padi \\
\hline \multirow{2}{*}{2} & Tersedia air dalam jumlah cukup & Padi - Padi - Palawija \\
\cline { 3 - 3 } 3 & Kurang air & Padi - Palawija - Palawija \\
& & Padi - Palawija - Bera \\
\hline
\end{tabular}

Kebutuhan Air Irigasi

Kebutuhan air irigasi ialah jumlah volume air yang diperlukan untuk memenuhi kebutuhan evapotranspirasi, kehilangan air, kebutuhan air untuk tanaman dengan memperhatikan jumlah air yang diberikan oleh alam melalui hujan dan kontribusi air tanah. Suatu pertumbuhan tanaman sangat dibatasi oleh ketersediaan air yang di dalam tanah. Kekurangan air akan mengakibatkan terjadinya gangguan aktifitas fisiologis tanaman, sehingga pertumbuhan tanaman akan terhenti.

\section{METODOLOGI PENELITIAN Lokasi Penelitian}

Awo Gading merupakan salah satu Desa yang ada di Kecamatan Lamasi, Kabupaten Luwu, provinsi Sulawesi Selatan, Indonesia dengan luas areal 346 Ha. Desa ini merupakan satu dari 9 desa dan kelurahan yang berada di Kecamatan Lamasi. Awo Gading terdiri atas empat dusun yaitu: Dusun Awo Gading, Dusun To'arogo, Dusun Panglawa, dan Dusun To'Pongo.

Peneliti mengambil lokasi penelitian pada Desa Awo Gading khususnya pada areal persawahan di dusun To'Pongo Kecamatan Lamasi yang mempunyai lahan seluas $92 \mathrm{Ha}$.

\section{Tahapan Penelitian}

\section{Tahap Persiapan}

Tahap persiapan yang dimaksudkan adalah survey lokasi yang merupakan langkah awal yang dilakukan untuk mendapatkan gambaran sementara tentang lokasi penelitian, pengumpulan literatur-literatur dan referensi yang menjadi landasan teori, serta pelaksanaan pembuatan proposal pelaksanaan. Dengan adanya tahap persiapan ini akan memberikan gambaran tentang langkah-langkah yang akan diambil selanjutnya.

2. Pengumpulan Data

Pengumpulan Data Primer

Data-data primer adalah data yang di dapat oleh peneliti dengan cara survey langsung ke lapangan. Data-data primer dibutuhkan untuk menyempurnakan data-data sekunder yang telah di dapat.

Pengumpulan Data Sekunder

Data-data sekunder dibutuhkan sebagai data dasar atau data awal untuk pelaksanaan penelitian yang kemudian disempurnakan dengan data-data primer. Keberadaan data-data sekunder ini cukup penting bagi peneliti terutama untuk mengetahui kondisi eksisting lokasi penelitian. Dalam pengumpulan data-data sekunder ini peneliti memperoleh dari beberapa pihak yang terkait. Adapun data-data 
sekunder yang dikumpulkan dalam penelitian ini meliputi: data jadwal tanam, data curah hujan, dan data klimatologi.

3. Analisis Data

Tahapan analisa data yang perlu dilakukan dalam penelitian ini adalah:

a) Analisis Klimatologi yaitu menentukan besarnya nilai evapotranspirasi dengan menggunakan Metode Penman Modifikasi karena data-data yang di dapat sesuai dengan metode ini.

b) Analisis Kebutuhan Air Irigasi yang terdiri dari: (1)Penyiapan lahan dan menentukan kebutuhan air selama penyiapan lahan, (2)penggunaan konsumtif, (3)perkolasi, menentukan daya perkolasi pada areal irigasi, (4)penggantian lapisan air dilakukan menurut kebutuhan, dan (5)curah hujan dengan menentukan curah hujan efektif besarnya R80 kemudian menentukan curah hujan efektif untuk padi.

\section{HASIL DAN PEMBAHASAN}

\section{Pertumbuhan Produktivitas (Produksi dan Produktivitas Padi)}

Total produksi padi merupakan perkalian antara luas areal panen dengan produktivitas.

Persamaan produksi padi dirumuskan sebagai berikut :

$\mathrm{QPt}=\mathrm{LAPt} \times \mathrm{Qt}$

Persamaan produktivitas dirumuskan sebagai berikut :

$\mathrm{Qt}=\mathrm{QPt} / \mathrm{LAPt}$

Dimana :

QPt = Produksi padi tahun ke $\mathrm{t}$ (ton)

LAPt = Luas areal panen tahun ke $\mathrm{t}$ (ha)

Qt = Produktivitas tahun ke $\mathrm{t}$ (ton/ha)

Perhitungan :

Musim tanam I (Musim Tanam Rendeng)

$\mathrm{Qt}=\mathrm{QPt} / \mathrm{LAPt}$

$=699,2 / 92$

$=7,6$ ton $/$ ha

$\mathrm{QPt}=\mathrm{LAPt} \times \mathrm{Qt}$

$=92 \times 7,6$

$=699,2$ ton

Musim tanam II (Musim Tanam Gadu)

$\mathrm{Qt}=\mathrm{QPt} / \mathrm{LAPt}$

$=662,4 / 7,2$

$=7,2$ ton $/ \mathrm{ha}$

$\mathrm{QPt}=\mathrm{LAPt} \times \mathrm{Qt}$

$=92 \times 7,2$

$=662,4$ ton 
Tabel 2. Hasil Produksi Pertanian

\begin{tabular}{|c|c|c|}
\hline Jenis & $\begin{array}{c}\text { Produktivitas }(\mathrm{Qt}) \\
\text { ton } / \mathrm{ha}\end{array}$ & $\begin{array}{c}\text { Produksi }(\mathrm{QPt}) \\
\text { ton }\end{array}$ \\
\hline 1. Padi & & \\
\hline $\begin{array}{l}\text { - Padi Musim Rendeng (Padi Musim } \\
\text { Hujan) }\end{array}$ & 7,6 & 699,2 \\
\hline $\begin{array}{c}\text { - Padi Musim Gadu (Padi Musim } \\
\text { Kemarau) }\end{array}$ & 7,2 & 662,4 \\
\hline
\end{tabular}

\section{KESIMPULAN}

Berdasarkan analisis dan pembahasan yang telah dilakukan maka dapat diambil kesimpulan sebagai berikut:

a) Berdasarkan perhitungan hasil produksi pertanian dapat disimpulkan bahwa produktivitas padi musim rendeng (padi musim hujan) sebesar 7,6 ton/ha menghasilkan produksi pertanian yang cukup besar yaitu sebesar 699,2 ton. Sedangkan produktivitas padi musim gadu (padi musim kemarau) sebesar 7,2 ton/ha hanya menghasilkan produksi pertanian sebesar 662,4 ton.

b) Dari hasil analisis pengaruh kebutuhan air terhadap hasil produksi pertanian pada lahan persawahan dusun To'Pongo Desa Awo Gading dapat digambarkan bahwa semakin besar tingkat produktivitas akan sejalan dengan kebutuhan air terhadap tanaman.

\section{DAFTAR PUSTAKA}

Direktorat Jenderal Sumber Daya Air. (2010). Standar Perencanaan Irigasi Kriteria Perencanaan Bagian Jaringan Irigasi KP-01.

Departemen Pekerjaan Umum Direktoral Jenderal Pengairan. (2010). Standart Perencanaan Irigasi KP - 01, 02, 04, dan 06. Jakarta: Badan Penerbit Pekerjaan Umum.

Hadisusanto. (2014). Aplikasi Hidrologi. Malang: Jogja Mediautama.

Hadisusanto. (2015). Aplikasi Hidrologi. Malang: Jogja Mediautama.

Monica S. (2013). Analisis Kebutuhan Air Irigasi Pada Daerah irigasi Tugumulyo Kabupaten Musi Rawas Sumatra Selatan. Arsip Laporan Tugas Akhir Perpustakaan Jurusan Teknik Sipil Universitas Sriwijaya.

Purwanto dan Ikhsan, Jazaul. (2014). Analisis Kebutuhan Air Irigasi Pada Daerah Irigasi Bendung Mrican. Jurnal Ilmiah Semesta Teknika. Vol.9, No. 1,206:83 93. Jurusan Teknik Sipil, Universitas Muhammaddiyah Yogyakarta.

Sidharta, SK. (2013). Irigasi dan Bangunan Air. Jakarta: Gunadarma.

Sosrodarsono, Suyono dan Takeda, Kensaku. (2014). Hidrologi untuk Pengairan. Jakarta: Pradna Paramita.

Soemarto, CD. (2013). Hidrologi Teknik. Surabaya: Usaha Nasional.

Van de Goor G.A.W. dan Zijlstra G. (KP-01). (2010). Irrigation requirements for doublecropping of lowland rice in Malaya. Wageningen: ILRIPublication 14. 
PENA TEKNIK: Jurnal Ilmiah Ilmu-Ilmu Teknik

Volume 4, Nomor 1, Maret 2019: 47 - 51

Halaman ini sengaja dikosongkan 